\title{
A AMIZADE PARA NIETZSCHE: UMA ARENA DE MAL ENTENDIDOS ${ }^{1}$
}

Jelson Roberto de Oliveira (PUCPR) ${ }^{2}$

jelsono@yahoo.com.br

Resumo: Pretende-se mostrar a importância da amizade no âmbito da reflexão sobre a incompreensibilidade da riqueza vital experimentada como vivência mais própria e como Nietzsche chega, pela relação amical, à formulação de uma nova aurora do pensar, agora situado no campo das vivências, cuja tradução foge dos sistemas da compreensibilidade. Nesse cenário, a amizade aparece como arena para mal entendidos porque fomenta a possibilidade de uma relação traduzida pelo pronome plural nós - um signo da relação que se efetiva como impavidez, liberdade e afirmação individual, com vistas à constante autossuperação de si.

Palavras-Chave: amizade; incompreensibilidade; autossuperação.

\section{INTRODUÇÃO}

A importância e a constância do tema da amizade nos escritos de Nietzsche são equivalentes à desídia com que o tema vem sendo tratado pelos comentadores em geral. As fortes alternativas de interpretação conduzem rapidamente da complexidade do exame à riqueza de possibilidades, já que a amizade pode ser entendida como uma chave de entrada no edifício labiríntico da filosofia do autor de Assim falou Zaratustra. Se, por um lado, Nietzsche explicita, mormente nas obras que formam o chamado segundo período de sua

\footnotetext{
${ }^{1}$ Recebido: 04-07-2011/Aprovado em 18-10-2011/Publicado on-line: 30-12-2011.

${ }^{2}$ Jelson Roberto de Oliveira é Professor-adjunto do programa de pós-graduação da Pontifícia Universidade Católica do Paraná, Curitiba, Brasil.
} 
produção, a importância da amizade como crítica à moral da compaixão, nos escritos da maturidade, grosso modo, ela está ligada à sua crítica à modernidade e à insistente perspectiva de autossuperação de si, o que, no caso da amizade, passa pela reinterpretação das relações humanas na perspectiva de um novo nós.

Esse é o ponto de partida deste artigo, que analisa o tema da amizade no corpus filosófico de Nietzsche, um autor reconhecido por suas afirmações em torno da necessidade da solidão, bem como por suas intensas experiências de rompimento e renúncia. É na amizade que se estabelece a relação entre ipseidade e alteridade, transformada numa espécie muito própria de intersubjetividade a partir da afluência e solidificação dessas duas perspectivas. Contudo, o tipo de intersubjetividade possível em Nietzsche, como tentaremos mostrar neste texto, não é o da afirmação de uma subjetividade em sentido tradicional (o autor recusa o sujeito como elemento metafísico peculiar), porque o caminho de acesso a um pretenso eu, bem como de um outro, está definitivamente interditado. A relação estabelecida entre dois indivíduos humanos, portanto, não passa pela compreensão das partes, mas por um campo de incompreensibilidade no qual os dois polos da relação intersubjetiva outorgam uma radicalidade crítica que impede que a amizade seja mais do que uma relação na qual o eu e o outro formam-se na dúvida, na ilusão, no embuste - dado que o conhecimento pleno desses dois polos é tido como impossível. Porque assim, sem eu e sem outro (a não ser um como invenção do outro), não é mais possível falar em comunicação ou mesmo de busca de consenso no uso da palavra. Há, pois, na amizade, um novo horizonte de intersubjetividade que é, segundo queremos mostrar aqui, traduzida por $\mathrm{Ni}$ - 
etzsche no uso do pronome nós durante boa parte de seus textos.

Trata-se de um processo de autossupressão de si como resultado do contínuo processo de tornar-se, por cuja via $\mathrm{Ni}$ etzsche expressa essa recusa do eu e do outro, porque essas instâncias estão amparadas numa concepção fixa de ser, em direção ao qual o autor contrapõe a noção de devir como constância no tornar-se; compreender é se igualar, enquanto um tornar-se o indivíduo nunca pode ser submetido ao processo de "igualamento", porque sequer pode ser comunicado. É por isso que, na amizade, não se pretende nenhum igualamento, pois a verdadeira igualdade é aquela que reconhece a pura desigualdade das posições e para a qual Nietzsche faz uso do conceito de Spielraum. Vejamos como essa argumentação é levada a cabo.

\section{O IMPERATIVO DA AUTOSSUPERAÇÃO DE SI}

Para Nietzsche, o humano forma-se na existência, a partir de seu jogo de forças, e, desde suas interpretações, cria para si mesmo regras absolutamente antiteleológicas que conduzem a essa desejada autossuperação. É esse, na medida, o sentido do dístico "torna-te aquilo que és", presente no parágrafo 270 de A Gaia Ciência, pelo qual cada humano singular é apresentado como autoformador de si mesmo, num jogo extramoral cujo programa ético se efetiva como constante superação de si para tornar-se aquilo que se é: "Du sollst der werden, der Du bist" (GC, 270 $)$ assim, não pas-

\footnotetext{
${ }^{3}$ Neste artigo usaremos as siglas convencionais para citação dos escritos de Nietzsche: $H H$ I (Humano, Demasiado Humano, v. I); BM (Além de Bem e Mal); A (Aurora); GC (A Gaia Ciência); GM (Para a genealogia da Moral); KSA (Sämtliche Werke. Kritische Studienausgabe edição crítica em 15 volumes organizada por Giorgio Colli e Mazzino Montinari - a sigla será Cont.
} 
sa de um comando íntimo paradoxal que exige o cumprimento de algo que se apresenta justamente fora da exigência imperativa.

Para Babich $(2006,1)$ é preciso partir de uma diferenciação quanto ao que significa esse imperativo ético de Nietzsche, pois, ao formulá-lo, o filósofo se diferenciaria de duas formas correntes de compreensão do que seria o imperativo: uma o "imperativo prático" e outra o "imperativo conservativo", frequentemente usados nas éticas tradicionais. Os primeiros, segundo a autora, "exortam-nos a alterar nossas vidas, a não ser aquilo que nós (já) somos, mas partindo de possibilidades ideais geralmente contrárias às circunstâncias ou fatos imediatos, eles impõem a idéia de tornarmo-nos aquilo que nós não somos (por enquanto)". Por isso mesmo, não seria esse tipo de imperativo que Nietzsche tem em mente ao estabelecer o "Du sollst der werden, der $D u$ bist”, um móbil tão central no seu projeto filosófico, já que seu ponto de partida não é uma insatisfação com o que se é e uma consequente exigência de mudança. Mas o dístico nietzschiano não remete, também, a algum "imperativo do tipo conservativo", que exige a permanência no que se está, que se torne algo que já se é, ou que se apegue a algo que não pode ser mudado. Esse segundo tipo de imperativo evoca a resistência às transformações, enquanto os primeiros exigem-nas. Ambas as circunstâncias estão, certamente, em desacordo com a intenção nietzschiana.

Pode-se afirmar que o imperativo de Nietzsche é um comando tanto de mudança quanto de permanência, por-

seguida do número do volume, número do fragmento e página da edição); EH (Ecce Homo); $C I$ (Crepúsculo dos Ídolos), ZA (Assim falou Zaratustra). Seguindo as letras, para as obras publicadas, constarão os números arábicos referentes ao número do aforismo da obra. 
que é na mudança que se efetiva aquilo que se é, ou seja, é na efetivação da força que a força se apresenta. Segundo Babich, Nietzsche transforma esse tornar-se futuro numa consumação regressiva do presente e faz disso o lema de sua própria vida e de sua própria filosofia. Essa é a mensagem do amor fati na epígrafe afixada a Ecce homo. A injunção aforística de Nietzsche, por isso mesmo, exigira uma alteração do verso 72 das Segundas Odes Pintias, de Pindaro, que dizia: "aprenda a ser o que você é" ${ }^{4}$. Nietzsche não faz uma tradução do verso, mas uma invocação ou alusão que retira propositalmente o verbo aprender $(\mu \alpha \theta \omega v-\text { maton })^{5}$ do contexto do aforismo. Em Píndaro, o verso servia de elogio suplementar dirigido a Hieron ${ }^{6}$, o campeão da corrida de carros, e parte daquilo que é preciso para se tornar nobre: adquirir a verdadeira sabedoria, aprender de si mesmo a superar a si mesmo. Nesse jogo do duplo e do paradoxo se revela a intenção de Nietzsche em explicitar o fato de que, como buscadores do conhecimento, permanecemos na verdade desconhecidos de nós mesmos e só reconhecendo-nos enquanto tal é que podemos inaugurar o caminho que nos leva até quem nós verdadeiramente somos. O lema píndaronietzschiano não é outra coisa senão um elogio que leva o humano para dentro de si mesmo em busca da autossupe-

\footnotetext{
${ }^{4}$ Outras traduções possíveis, seguindo as sugestões de Babich, seriam: "tornar-se aquilo que se é, tendo aprendido o que isso é"; "seja verdadeiro por si mesmo agora que você aprendeu que tipo de homem você é"; "tendo aprendido, torne-te aquilo que você é"; ou simplesmente: "Seja quem você sabe que é".

${ }^{5}$ Genoi' hoios essi mathon [aprenda a ser o que você é].

${ }^{6}$ A segunda das doze Odes Pínticas fora escrita para Hieron, vencedor da corrida de carros (c. 475) e contém 176 versos. O tema da segunda Ode é o dever do reconhecimento de benefícios recebidos e cita os exemplos de Íxion e de Radamante. As Odes são versos escritos para os vencedores das Olimpíadas pan-helênicas realizadas quadrianalmente em Delfos, na Antiga Grécia. Diz os versos 7-10 da VII Ode Olímpica: "[...] assim eu, mandando aos atletas vitoriosos / esse líquido néctar, dom das Musas,/ doce fruto do espírito, / dou alegria aos vencedores de Delfos e Olímpia. / Felizes aqueles a quem cerca a fama gloriosa!".
} 
ração, já que o convite a se tornar aquilo que se é acaba desvelando não apenas um potencial humano "ou uma possibilidade de ser, mas o que já está consumado, medido e realizado (sem para isso se contar com uma 'consciência')" (BABICH, 2006, 2).

Como um elogio paradoxal, o que Nietzsche desvela é a necessidade de que cada indivíduo singular se torne, eticamente falando, legislador de si próprio (BM, 211). Em outras palavras: tornar-se o que se é articula, a um tempo, a necessidade de aceitação do que se é e a exigência de transformação a partir de uma autossupressão consciente de si mesmo e da consequente alteração/mudança de si. Todo esse processo, entretanto, ocorre sem apelo ao controle da consciência, o que explica o abandono, por parte de Nietzsche, do verbo aprender e a sua substituição pelo simples tornar. Ou seja, o que o filósofo explicita é que o tornar-se o que se é não é, necessariamente, um projeto ético (guiado por um ethos) no sentido do seguimento de alguma norma externa ou mesmo da consignação de um pensamento autossugestivo. O tornar-se é um apelo ao que há de mais legítimo na experiência vital e que, no limite, permanece desconhecido para o eu consciente, abrindo espaço para aquilo que permanece no estado da incompreensibilidade.

Trata-se de um imperativo embasado num pathos que funda o reino da grande liberdade diante da lei, aquela que não mais submete o humano ao campo do nivelamento, da igualdade e da universalização. A grande liberdade é aquela que faz cada indivíduo usar da moral como "auxílio a serviço da vida" (GC, 370) e como adubo no cultivo dos grandes homens, aqueles que, na autossuperação de si, não seguem mais um imperativo de dever, no sentido do cumprimento de normas que tornem as relações humanas previsíveis e 
controladas (segundo o modelo de um ethos), mas justamente por uma espécie de relação autorregulada que tem, segundo a nossa hipótese, na amizade a sua concretização. Em outras palavras: só na amizade, como modelo relacional de espíritos livres, o imperativo do "Du sollst der werden, der Du bist" faz algum sentido.

\section{A AMIZADE COMO SPIELRAUM: O PROBLEMA DA INCOMPREENSIBILIDADE}

Em KSA 12 (1[182], p. 50), Niezsche escreve: "Ser compreendido? Vocês sabem o que isso significa? - Comprendre c'est egaler”. A passagem não é apenas uma denúncia do processo de homogeneização provocado pela compreensão como anulação das diferenças e das propriedades individuais, mas também uma recusa da "vontade de sistema" (considerada uma "falta de retidão" [CI, Máximas e flechas]) que se forjou no seio da filosofia como requisito moral. Se, como escreve o filósofo no aforismo 284 de Além de Bem e Mal, "toda comunidade torna, de algum modo, alguma vez, em algum lugar - comum, vulgar”, a amizade é o ambiente no qual é possível fugir dessa regra pela via da afirmação de si no experimento da solidão ${ }^{7}$. Trata-se de uma preferência que se traduz como um luxo de viver entre homens que suportam a incompreensão: "É preciso, para se dar esse verdadeiro luxo de gosto e moralidade, não viver entre grosseirões do espírito, mas entre homens nos quais os mal-entendidos e equívocos divergem por sua sutileza” (BM, 283). É como sutileza, portanto, que os homens mais nobres suportam os

\footnotetext{
${ }^{7}$ Sobre a relação entre solidão e amizade cf. A solidão como virtude moral em Nietzsche (Curitiba: Champagnat, 2010).
} 
mal-entendidos, uma esperteza e refinamento no convívio alcançado por aqueles que compreenderam o vetor de incompreensibilidade que se efetiva por trás das vivências mais ricas e férteis e que, por isso mesmo, não cabem na palavra que tenta, desesperadamente, comunicar. Os amigos são os que suportam o jogo (Spiel) e fomentam o que é próprio como condição relacional fluida e vivificada não pela explicação - ou conceitualização - do que é experimentado, mas pela interpretação evasiva do que é vivido.

Como crítica à igualdade das relações, à igualdade como valor ético-político moderno por excelência e ao processo de igualitarização como desarmamento de diferenças, a amizade é tida por Nietzsche como um ambiente no qual se efetiva um tipo de relação marcada pela necessária e legítima incomunicabilidade das vivências próprias de cada indivíduo ${ }^{8}$ (como certo direito de tornar-se constantemente quem se é - o que implica, necessariamente, uma alteração constante de si) e, por ser tal, não pode ser partilhada num sentido de fazer-se compreender através de processos comunicativos da linguagem. Só na amizade o imperativo da autossuperação tem factibilidade porque, enquanto relação formadora, ela está baseada na exigência da constante afirmação de si através das vivências mais próprias que permanecem no campo do incomunicável e do inaudito sempre de novo alterado. Se, de um lado, os conceitos e as doutrinas, as normas da moralidade e as regras de comportamento, marcados pela linguagem corrente, não possibilitam qualquer jogo/margem de manobra porque, ao tentarem comunicar o incomunicável, não o fazem a não

\footnotetext{
${ }^{8}$ A esse respeito, cf. a tese do prof. Jorge Viesenteiner, "Experimento e experiência: a dimensão da vida como pathos", principalmente o capítulo 3, item 3.1.1, intitulado "O projeto crítico de inversão da compreensibilidade", em cuja referência constam os trabalhos do prof. Werner Stegmaier.
} 
ser de forma prematura, imatura e simplificadora, a amizade se estabelece a partir da capacidade de suportar a incompreensibilidade das vivências. E essa é mesmo a condição mais fundamental desse tipo de relação. A fórmula nietzschiana para expressar essa ideia é justamente a noção de Spielraum?

O contrário ocorre na moral gregária, que está baseada na crença na linguagem como mecanismo de acesso a uma pretensa verdade sobre o eu e o outro, ou seja, numa ação universal de compreensibilidade total fomentada pelo ideal de clareza exigida nas relações humanas. Aliás, é o princípio da compreensibilidade que impõe verdade à filosofia e à própria moral na medida em que legitima, pelo consenso, o acesso ao que é pretensamente considerado verdadeiro. $\mathrm{O}$ ra, o que não é compreendido não pode ser logo descartado como erro, até porque, segundo Nietzsche, a verdade expressa pela linguagem não passa de uma pretensão, carregada de abreviaturas e ilusões. Nesse tipo de relação gregária, a validade da verdade dá legitimidade para um tipo de relação na qual o indivíduo seria anulado em benefício da unilateralidade de uma crença que se apresenta como supraindividual, na medida em que se traduz acima do que é vivenciado no campo individual. Trata-se de um processo de familiarização e anulação do diferente e do divergente que, no limite, manifesta o medo da vida e a fraqueza quanto às capacidades de vivenciar as aventuras formuladas pela existência mais própria. Instala-se a vulgaridade como negação da individualidade.

Ao recuperar o valor da amizade, Nietzsche oferece, en-

\footnotetext{
${ }^{9}$ Cf. $H H$ I, 211; $A, 119 ; B M, 27 ; K S A 12,1[182]$, p. 50; KSA 8, 9[1], p. 131; KSA 12, 9[139], p. 414; KSA 13, 11[400], p. 185; KSA 13, 16[7], p. 485.
} 
tão, à filosofia, a possibilidade de reavaliação do princípio regente do universalismo que tudo abrevia e simplifica, torna familiar e desgastado, em detrimento do que é complexo e pleno de sentidos - e, por isso mesmo, permanece obscuro no campo do não-totalmente-desvelado. A eliminação do individual e do próprio passa pela ascensão do conhecido e inteligível: tornar claro e compreensível é, sempre, tornar fraco e vulgar, porque se trata de comunicar algo incomunicável. Esse é o modelo da "moral do rebanho", que permaneceu historicamente vinculada à moral da compaixão, que, por sua vez, busca o reconhecimento universal de uma dor comum como critério da ação moral. É o que exige uma crítica, portanto. Por isso, como Spielraum, a amizade é um espaço de superação desse mecanismo, por possibilitar a riqueza interpretativa de uma relação que permanece nas raias da incompreensibilidade porque se dá como vivência, como aceitação e apologia da vivência mais própria, aquela que é condição própria da relação. $\mathrm{Na}$ amizade, o indivíduo tem lugar, é ele, como expressão de vivências próprias, que é celebrado. Se na moral gregária, marcada pela compaixão, o homem é carente de sentido histórico, na amizade o personagem está ligado, pela via histórico-fisio-psicológica, àquilo que lhe é mais particular.

A amizade, como Spielraum, é o espaço, o ambiente, a margem de manobra, um livre curso, um livre jogo de incompreensibilidade. Trata-se de um espaço de direito, conquistado pela via das vivências. Temos, portanto, dois motes que se articulam em torno da noção de Spielraum e a ligam à amizade. [1] $\mathrm{Na}$ amizade, o homem não é mais um "conceito" universal, mas uma rotatividade, uma mudança, uma aventura, e é enquanto tal que ele mesmo (na forma de um nós insistentemente retomado por Nietzsche nos seus 
escritos) se torna incompreensível, posto que não parte mais da invariabilidade e fixidez de um sentido único. [2] É como lugar supremo da con-vivência mais individual que a amizade se estabelece enquanto espaço de incompreensibilidade porque nela se celebram as condições existenciais de cada um, algo só possível de ser suportado por aqueles (nós) que se desvencilharam da necessidade de vulgaridade que se esconde por trás dos processos de comunicação. Na amizade, o verdadeiro espírito livre se revela como preparado e experimentado nas vivências mais próprias e, portanto, absolutamente incompreensíveis pela via de uma comunicação vulgar.

A primeira aparição da noção de Spielraum na obra nietzschiana publicada se dá no aforismo 211 de Humano, demasiado humano, no contexto do exame psicológico da produção da obra de arte e da ligação da obra com as vivências mais próprias. A comparação, nesse aforismo, é entre Aquiles e Homero: "um tem a vivência, a sensação, o outro as descreve" (HH I, 211). No caso de Homero, o que ele faz é dar nome para os afetos e sua arte está em "adivinhar bastante" justamente onde pouco sentiu ou vivenciou. $O$ artista é aquele que finge ter vivenciado as paixões que descreve com a finalidade de dar mais legitimidade à sua produção. Nesse contexto, o Spielraum aparece como o "livre jogo" da ira e do desejo experimentados pelos indivíduos, de forma ilusória, como critério de legitimidade e aprovação de sua arte. O que Nietzsche constata é que, geralmente, o artista necessita do contrário: ele não pode se deixar devorar e consumir pelas vivências ("quem a vivencia [a paixão], não a descreve em peças teatrais, sons ou romances" [HH I, 211]). Como "indivíduos desenfreados", os artistas deixam de sê-lo porque perdem a capacidade de 
controle. Portanto, a Spielraum é o ambiente da vivência que não pode ser freado ou controlado, a não ser como experiência vital.

Em Aurora, 119, essa incompletude e descontrole dos impulsos é retomado como tema ligado justamente à invenção da própria vida. O aforismo, intitulado "Viver é inventar" começa tematizando a incapacidade de que o indivíduo consiga, mesmo com todo o esforço na direção do autoconhecimento, dar nome aos impulsos, porque não há nenhum "nexo racional" capaz de organizar os eventos impulsivos que formam as vivências diárias. Tidas como "meios de alimentação", as vivências são descritas por $\mathrm{Ni}$ etzsche como "distribuídas com mão cega", numa espécie de jogo do acaso que tem no sonho um exemplo bastante interessante: o sonho, escreve o filósofo, "tem precisamente o valor e o sentido de, até certo grau, compensar a casual ausência de 'alimentação' durante o dia” (A, 119), ou seja, através do sonho alguns impulsos podem encontrar formas de saciação ilusória. As criações oníricas são apresentadas então como uma espécie de Spielraum, porque "dão margem e desafogo aos nossos impulsos", numa liberdade que não poderia ser alcançada na "vida de vigília" porque esta está acompanhada sempre pela vontade de organização, ordem e conhecimento. A "vida que sonha" é mais "inventiva e desenfreada" do que a vida que vigia, ainda que Nietzsche acrescente uma observação decisiva: a de que em vigília o indivíduo não escapa das interpretações oníricas. Assim, todos os "juízos e valorações morais são apenas imagens e fantasias sobre um processo fisiológico de nós desconhecido, uma espécie de linguagem adquirida para designar certos estímulos nervosos" (A, 119). Nesse campo, a linguagem mesma não passaria de interpretação, fantasia ou 
imagem que simboliza e simula algo que não pode ser comunicado a não ser como signo ${ }^{10}$. Ou seja, a Spielraum é um campo simbólico no qual a linguagem não remete mais a um significado, mas apenas a um signo que forma um "texto não sabido, talvez não 'sabível', porém sentido”. Por isso, nesse ambiente, as vivências são invenções postas em funcionamento a partir de impulsos variados que se atiram sobre os acontecimentos vitais como suas "presas" e acabam mobilizando as ações humanas nesse ou naquele sentido, sempre sob a interferência decisiva do que não pode ser dito ou comunicado, apenas vivenciado. É isso o que torna o reino do pensamento, segundo Nietzsche, um "reino da superfície" (A, 125) que se traveste de "reino da liberdade" quando na verdade só angaria carência de compreensão.

É justamente essa carência de compreensibilidade, tantas vezes evocada por Nietzsche, que aparece como característica do espírito livre ${ }^{11}$ no aforismo 27 de Além de bem e mal. O filósofo inicia o capítulo, intitulado justamente "O Espírito Livre", tematizando a capacidade do homem em viver numa "curiosa simplificação e falsificação" (BM, 24), ligando a ignorância à liberdade e a vontade de saber a uma profunda incompreensão, "liberdade, imprevidência, despreocupação, impetuosidade, jovialidade na vida”. Para Nietzsche, a vontade de saber da ciência esteve sempre as-

\footnotetext{
${ }^{10}$ Pode-se afirmar que, nesse sentido, ocorre no pensamento de Nietzsche uma substituição da ideia de significado (o que algo significa), associado ao exame frequente da linguagem realizada nos escritos do primeiro período, principalmente no que tange à noção de metáfora, pela ideia de signo (o que simboliza), como expressão daquilo que não mais representa um sentido, mas apenas simula algo que não pode ser comunicado ou mesmo compreendido.

${ }^{11}$ É interessante notar que o conceito de espírito livre, que aparece como subtítulo da obra $\mathrm{Hu}$ mano, demasiado humano, está associado, no segundo período, à amizade. Uma pista a respeito dessa associação se encontra numa anotação da primavera-verão de 1877, na qual Nietzsche demonstra pretender escrever uma dedicatória na abertura da obra: "Aos amigos, saudação e dedicatória" (KSA 8, 22 [2], p. 379). A dedicatória, entretanto, é substituída pelo subtítulo.
} 
sentada sobre uma "base de vontade ainda mais forte, a vontade de não-saber, de incerteza, de inverdade" como um "refinamento" justamente daquela antiga vontade de saber. Esse refinamento tem razão de ser justamente devido ao reconhecimento da total simplificação praticada pela linguagem quando se trata de traduzir as vivências mais profundas. Toda ciência, na medida em que se expressa pela linguagem, não passaria de uma atividade risível e traduziria um "mundo simplificado, completamente artificial, fabricado, falsificado, e de como, involuntariamente ou não, ela ama o erro, porque, viva, ama a vida!" (BM, 24). Retoma-se assim o sentido de vida como invenção presente em Aurora, § 119. Como erro, a linguagem celebra a vida de forma mais refinada e intensa porque a vida não cabe na linguagem, porque esta não pode traduzir as vivências a não ser pela via da simplificação.

O aforismo seguinte, o 25 , inicia-se com um apelo à seriedade, mas toma corpo como ironia, apelando para o fato de que nenhum filósofo deve agora buscar o martírio em nome da verdade e deve tomar cuidado com a solidão que promove o espírito de vingança e que envenena. A tragédia da filosofia chegaria ao fim com a ascensão dessa novidade histriônica de que a verdade não é mais o seu alvo, de que uma boa dose de riso e de comédia tomou conta da tarefa filosófica. Como histrião é que esse filósofo, experimentado na solidão voluntária, retorna à praça do mercado - reconhecendo-se como "exceção" ele reconhece o quão interessante para ele pode ser a "regra" (BM, 26). A "parte necessária no currículo de todo filósofo, talvez a parte mais desagradável, mais malcheirosa, mais rica em decepções" passa a ser justamente esse "estudo do homem médio", que tem no cínico o seu exemplar "facilitador": "o homem su- 
perior terá os ouvidos atentos para todo cinismo grosseiro ou sutil, e se felicitará toda vez que um bufão sem pudor ou um sátiro da ciência prosear diante dele" (BM, 26), porque aí reside um exemplo daquele que reconhece em si a impossibilidade da compreensibilidade.

"É difícil ser compreendido", escreve Nietzsche na abertura do aforismo 27. Há uma imensa dose de incompreensão e mal-entendido se pensarmos nas vivências individuais mais próprias. Compreendendo a amizade como uma arena na qual há espaço para essa indolência da incompreensão e até para certa "sutileza na interpretação", Nietzsche escreve nesse fragmento - associando a amizade à Spielraum:

Mas no que toca aos "bons amigos", sempre muito indolentes e acreditando ter, como amigos, direito à indolência: é bom lhes conceder, antecipadamente, um espaço e uma margem [Spielraum] onde possam dar livre curso à incompreensão: - assim temos ainda do que rir; - ou então afastá-los inteiramente, esses bons amigos - e rir também. ${ }^{12}(B M, 27)$

Os "bons amigos" são aqueles que estão, enquanto iguais (no aforismo anterior, o 26, Nietzsche tinha escrito que "toda companhia é má, exceto a companhia dos i-

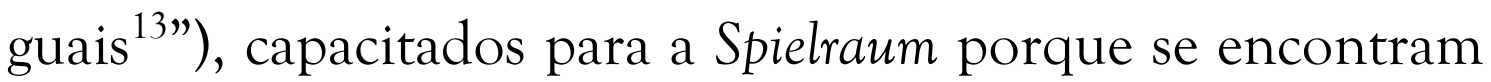
dispostos para a incompreensão e sabem rir dessa situação. $\mathrm{O}$ motivo do riso é o antídoto contra o ressentimento daqueles que, frente à incompreensão, alimentam a mágoa e

\footnotetext{
${ }^{12}$ Devo ao Prof. Viesenteiner $(2009,243)$ a intuição e a sugestão da tradução dessa passagem como "margem de atuação (Spielraum) e arena (Tummenplatz) para mal-entendidos", também em referência ao tema da amizade.

${ }^{13}$ Obviamente o sentido da igualdade perpetrada por Nietzsche não é aquele da igualação dos desiguais pela via da abreviatura e da negação das individualidades, mas aquele que a iguala na aceitação da desigualdade, mantendo as diferenças e divergências, o que faria a amizade algo próximo de uma "comunidade da discórdia".
} 
abastecem as relações com amarguras. Mesmo quando, caso não suporte a incompreensão, a amizade se vai, o amigo mantém o riso, porque entende que é essa a única possibilidade frente à vivência mais própria. Não à toa, o riso é a condição da amizade como Mitfreude, ou seja, partilha da alegria $^{14}$.

Sobre esse assunto, é interessante retomar, a título de exemplo, a relação entre Nietzsche e Rée ${ }^{15}$, tal como descrita no fragmento 279 da Gaia Ciência:

Nós éramos amigos e nos tornamos estranhos um para o outro. Mas está bem que seja assim, e não vamos nos ocultar e obscurecer isto, como se fosse motivo de vergonha. Somos dois barcos que possuem, cada qual, seu objetivo e seu caminho; podemos nos cruzar e celebrar juntos uma festa, como já fizemos - e os bons navios ficaram placidamente no mesmo porto e sob o mesmo sol, parecendo haver chegado a seu destino e ter tido um só destino. Mas então a todopoderosa força de nossa missão nos afastou novamente, em direção a mares e quadrantes diversos, e talvez nunca nos vejamos de novo ou talvez nos vejamos, sim, mas sem nos reconhecermos: os diferentes mares e sois nos modificaram! Que tenhamos de nos tornar estranhos um para o outro é a lei acima de nós: justamente por isso devemos nos tornar também mais veneráveis um para o outro! Justamente por isso deve-se tornar mais sagrado o pensamento de nossa antiga amizade! Existe provavelmente uma enorme curva invisivel, uma órbita estelar em que nossas tão diversas trilhas e metas estejam incluídas como pequenos trajetos - elevemo-nos a esse pensamento! Mas nossa vida é muito breve e nossa vista muito fraca, para podermos ser mais que amigos no sentido dessa elevada possibilidade. - E

\footnotetext{
${ }^{14}$ Sobre esse assunto cf. meu trabalho "Para uma ética da amizade em Friedrich Nietzsche", no qual apresento a relação entre amizade e alegria em contraposição ao modelo da ética da compaixão. Nietzsche articula, com isso, a Mitfreude com o neologismo Mitfrende contra a Mitleide (cf. PONTON, 2010)

${ }^{15}$ Ainda que isso tenha pouca importância do ponto de vista teórico, seguimos aqui a proposição de Robin Small, para quem, malgrado a insistência dos comentadores em referir essa passagem à relação entre Wagner e Nietzsche, trata-se, de fato, de um relato a respeito da amizade entre o filósofo alemão e Paul Rée. Small está amparado na afirmação de Lou Andreas-Salomé a esse respeito em seu livro Friedrich Nietzsche in seinen Werken (Dresden: Carl Reissner, 1924. p. 129). A esse respeito, cf. (SMALL, 2009, v e vi).
} 
assim vamos crer em nossa amizade estelar, ainda que tenhamos de ser inimigos na Terra.

Ao lado do rompimento com Wagner, o distanciamento de Paul Rée (de quem Nietzsche permanecera próximo por pelo menos sete anos, de 1873 a 1880) certamente foi um dos eventos mais marcantes na vida do filósofo alemão, seja em termos biográficos ou teóricos, já que Rée está ligado a um dos momentos mais cruciais da vida de Nietzsche, justamente aquele no qual o filósofo alemão busca a afirmação de um pensamento próprio. Esse aforismo, no seu corpus poético, expressa o sentido mais profundo desse acontecimento no que tange à concepção de amizade, que teve seu auge no idílio de Sorrento, logo após o rompimento decisivo com o Wagner de Bayreuth: o outro, sendo outro, não pode se tornar um mesmo e, assim, deve continuar vivenciando a si mesmo em suas próprias experiências vitais. Mesmo aí, o rompimento, na medida em que emerge como necessidade, é celebrado como festa, ou seja, é vivenciado sem rancor ou ressentimento. Então a vida mesma, aquela "todo-poderosa força de nossa missão", aciona a sua urgência e exige distanciamento para que cada um seja aquilo que é, como sinônimo do que não se compreende.

Várias expressões remetem, nesse parágrafo, a essa ideia: "que tenhamos de nos tornar estranhos um para o outro" (porque cada um mantém a si mesmo num campo próprio de vivências incomunicáveis); uma "lei acima de nós" (que se revela desconhecida); "tornar mais sagrado o pensamento de nossa antiga amizade" (é o desconhecido acima deles que torna ainda mais sagrada uma tal relação); "enorme curva invisível”, “órbita estelar" "tão diversas trilhas e metas" (expressões que remetem novamente ao que não é compreendido e para o qual é preciso elevar o pensamen- 
to); "vista muito fraca" (que não vê, que permanece no obscuro do incompreendido); e, finalmente, a ideia mesma de uma "amizade estelar", que se perde no infinito do cosmos e que, sendo de astros, impede qualquer proximidade. Todas essas expressões dão sinal do contorno dado por Nietzsche à amizade enquanto Spielräume, ainda quando ela mesma, enquanto relação de proximidade, se rompa e se mantenha distendida na eventualidade de uma perspectiva e de uma possibilidade, na dubiedade da palavra que não mais aproxima, no lance casual de um infinito que se abre e que alimenta a distância para que cada um siga a sua própria trajetória. Algo que não chega à consciência como reflexão e intencionalidade, mas que ocorre como absoluta necessidade - um radical ter de ser assim como é. O que o poético fragmento de A Gaia Ciência revela é a força de um pensador que se reconhece como solitário, marcado pelo apelo mais íntimo de liberdade plena e intensa autoafirmação. Uma amizade, no fim, que não prescinde de personalidade individual e, mais, a exige como condição.

É essa liberdade temerária uma marca de bem poucos, uma "prerrogativa dos fortes" que "penetra[m] num labirinto, multiplica[m] mil vezes os perigos que o viver já traz consigo" (BM, 29). O labirinto se torna, assim, a casa da amizade, a arena na qual o indivíduo se perde de si mesmo e do outro e vive o seu maior perigo: ser "despedaçado por algum Minotauro da consciência”. A metáfora do monstro que habita a casa monstruosa na forma de uma monstruosidade cujo resultado é a anulação da razão que ordena, direciona e cria metas, é o símbolo criado por Nietzsche para expressar a poderosa ideia daquilo que não pode ser comunicado e, por isso, permanece como anomalia para a filosofia tradicional. Por essa via, o próprio pensamento 
que se reconhece nas raias da incompreensibilidade formase como teratologia positiva, pela qual as deformações do pensar se revelam como única saída para o próprio pensamento, caminho pelo qual o próprio pensamento se pensa em deformidades e se estabelece como astigmatismo de sentido, por reconhecer em si mesmo a veracidade que tanto afugenta aqueles que ainda recriminam essa função filosófica como um delito imperdoável.

\section{NÓS: O PRONOME INCOMPREENSÍVEL}

Em Nietzsche, a exigência de refinamento ganha um contorno especial: a suspeita se transforma em instrumento filosófico e a própria filosofia uma atividade da suspeita. "Quando mais desconfiança, mais filosofia", escreve Nietzsche (GC, 346). A suspeita é o modo como Nietzsche trata a forma de pensar que ocorre como incompreensibilidade e, como tal, exige amigos - da verdadeira sabedoria - selecionados e preferidos. Trata-se, então, de um critério de seleção de pares pela via de uma filosofia que ocorre como "olhar oblíquo e malicioso a partir de todos os abismos da suspeita" (BM, 34).

Para isso, surge o enigmático pronome "nós", retomado por Nietzsche em vários vieses. "Nós, os impávidos" é título do livro V de A Gaia Ciência: é essa intrepidez e coragem dos espíritos livres que se revela como conquista de um chão próprio de indivíduos iguais vivendo em amizade. $\mathrm{O}$ "nós" é a metáfora de Nietzsche para a relação enigmática que ocorre no labirinto. $\mathrm{O}$ pronome pluraliza as possibilidades de uma relação que ocorre como distanciamento da massa pela via da aceitação da incompreensibilidade e, ainda, da compreensão do que permanece não compreendido 
pela maioria (no caso do aforismo 343, a morte de Deus). A "nova aurora" que ilumina o "nós, filósofos e 'espíritos livres”" (GC, 343) é o horizonte aberto e livre que se espaça para os barcos em busca de aventura no mar: "o nosso mar está novamente aberto”, exclama Nietzsche como quem celebra jubilosamente um novo tempo para a filosofia, no qual volta a ser permitida "a ousadia de quem busca o conhecimento", agora a partir de outro patamar, justamente o que se revela pela via da incompreensibilidade, porque antes se efetiva como vida mesmo - vida como fonte do conhecimento:

In media vita. - Não, a vida não me desiludiu! A cada ano que passa eu a sinto mais verdadeira, mais desejável e misteriosa - desde aquele dia em que veio a mim o grande liberador, o pensamento de que a vida poderia ser uma experiência de quem busca conhecer - e não um dever, uma fatalidade, uma trapaça! - E o conhecimento mesmo: para outros pode ser outra coisa, um leito de repouso, ou um ócio para mim ele é um mundo de perigos e vitórias, no qual também os sentimentos heróicos têm seus locais de dança e jogos. " $\boldsymbol{A}$ vida como meio de conhecimento" [Das Leben ein Mittel der Erkenntniss] - com esse princípio no coração pode-se não apenas viver valentemente, mas até viver e rir alegremente! E quem saberá rir e viver bem, se não entender primeiramente da guerra e da vitória? (GC, 324)

$\mathrm{Na}$ amizade reúnem-se aqueles que celebram esse tipo de filosofar que é, sobretudo, um tipo de viver, a forma de vida alegre, aventureira, arriscada e perigosa que se efetiva até lá onde não há compreensibilidade. A radicalidade dessa nova aurora do pensar é tal que mesmo a pessoa gramatical do nós paira incompreendido. No parágrafo 346 de A Gaia Ciência Nietzsche questiona:

Quem somos nós, afinal? Quiséssemos simplesmente nos designar, com uma expressão mais velha, por ateu ou ímpio, ou ainda imoralista, não acreditaríamos nem de longe estar caracterizados com isso: somos as três coisas num estágio muito adiantado para que se com- 
preenda, para que vocês compreendessem, senhores curiosos, em que estado de ânimo alguém assim se encontra. (GC, 346)

O incompreendido não é apenas o mundo, mas agora o próprio nós que inventa o mundo, o próprio nós que é o mundo: "[...] um outro mundo que somos nós mesmos: numa inexorável, radical, profunda suspeita acerca de nós mesmos" (GC, 346). Para isso nenhuma palavra do antigo vocabulário serve mais, porque a linguagem já não diz o que não pode ser dito. Por isso Nietzsche destaca o "vocês" em contraposição ao "nós": os outros não compreendem que não há mais compreensão possível. $\mathrm{O}$ que o vocês não compreende é o que o nós vivencia com júbilo a própria libertação do reino da compreensibilidade e da necessidade dele.

É o que se encontra no aforismo 371, intitulado "Nós, os incompreensíveis", que "habitamos cada vez mais próximos dos raios" e dos perigos como um reconhecimento da "nossa sina". É esse o destino do nós que se encaminha pela via da suspeita: "mal entendidos, mal conhecidos, confundidos, difamados, mal escutados e ignorados" - o nós se apresenta em eterno crescimento e mudança (traduzidos, nessa passagem, pela metáfora da árvore que cresce sempre para cima impelindo suas raízes sempre para mais fundo). Abrindo-se para o aberto, a árvore traduz a sina do nós que se escancara nas alturas do risco e do perigo do que não é fundamento, do que não tem base, do que não pode ser dito. Por isso, a sua sina ainda é alegre e jubilar: "ela continua a ser o que não desejamos compartilhar nem comunicar, a fatalidade das alturas, a nossa fatalidade" (GC, 371). O nós tem um nosso que é seu modo próprio de partilhar a impossibilidade da partilha. Eis a fatalidade na qual se encontra 
arraigado. E como sina de um nós que é agora o centro nevrálgico de uma nova aurora do pensamento, o aberto é um novo infinito: "O mundo tornou-se novamente 'infinito' para nós: na medida em que não podemos rejeitar a possibilidade de que ele encerre infinitas interpretações" (GC, 374). A infinidade de perspectivas forma o "nosso novo "infinito" como tradução da abertura que desencobre a existência como miragem interpretativa e recusa a adoração do desconhecido ("mas quem teria vontade de imediatamente divinizar de novo, à maneira antiga, esse monstruoso mundo desconhecido?" [GC, 374]). O desconhecido vivenciado pelo nós é aquele cheio de "demasiada diabrura, estupidez, tolice de interpretação - a nossa própria, humana, demasiado humana, que bem conhecemos".

A mesma definição para o nós é dada no aforismo 381, no qual Nietzsche trata da grande saúde: "Nós, os novos, sem nome, de difícil compreensão, nós, rebentos prematuros de um futuro ainda não provado" (GC, 381). Mais uma vez, o nós se revela, assim, como parte da incompreensibilidade provada no estágio de "vivência mais sua" e nas aventuras e perigos que se traduzem numa forma de verdadeira seriedade, aquela que deriva do seu inverso, que nasce do riso e da aventura que rompe com a solenidade como sua "mais viva paródia involuntária” (GC, 381) e que, no fim, soa como atividade artística simbolizada pela música e pela dança.

Trata-se de um sentimento de alheamento e de distanciamento, traduzido por Nietzsche no título do aforismo 377 da mesma A Gaia Ciência: "Nós, os sem-pátria". O desterro do nós se traduz na não compreensibilidade de sua ação, pela dureza de sua sina. "Nós, filhos do futuro, como 
poderíamos nos sentir em casa neste presente?": o nós recusa o próprio consolo de uma pátria porque prefere o "tempo da transição”. Entre seus iguais, o nós se traduz como imagem de um júbilo tal com a vida que chega a viver por experiência, criando, assim, o critério seletivo da relação de amizade: "alegramo-nos com todos os que, como nós, amam o perigo, a guerra, a aventura, que não se deixam acomodar, capturar, conciliar e castrar [...]" (GC, 377). Essa é a condição para a - muitas vezes dolorosa - "elevação do tipo 'homem'.

O motivo da incompreensibilidade ganha corpo também na análise de Nietzsche a respeito do estilo e da escrita no parágrafo 381 do livro V da Gaia Ciência. "A questão da compreensibilidade", nesse aforismo, passa por um elogio da incompreensibilidade como critério voluntário de escotha e seleção de "ouvintes" e criação de uma "barreira contra 'os outros"”. O estilo cria distância e reduz a compreensão ao âmbito daqueles "que nos são aparentados pelo ouvido" (GC, 381). Nietzsche ataca, nesse parágrafo, o ideal que tenta fazer brotar a verdade absoluta da demora e da profundidade (ironizada sob a metáfora da incubação de um ovo) e afirma existirem verdades que são captadas pela pressa, pela surpresa e pela brevidade: "minha brevidade tem ainda outro valor: dadas as questões que me ocupam, tenho de dizer muita coisa brevemente, para que seja ainda mais brevemente ouvida" (GC, 381). O que Nietzsche critica é a crença de que quanto mais demorada, mais compreendida. $\mathrm{O}$ elogio da brevidade retoma o elogio da incompreensibilidade, já que na pressa da avaliação há tanta ignorância quanto na demora da análise. Saber menos, assim, pode ser menos perigoso do que saber demais. Por isso, o nós é retomado: "não nos confundimos com os ou- 
tros" e "nós somos algo diferente dos eruditos": enquanto o erudito explica numa retórica cheia, o nós se aventura no mínimo, preferindo mais "viver livre e com pouco alimento, do que preso e empanturrado" (GC, 381). Como perspectiva, o nós remete não a um presente, mas a uma possibilidade futura, a um por vir. Os nobres e destacados são personagens inventados como oportunidade de experimentação, reinterpretação, avaliação, transformação e fluidez (cf. GM II, 12).

Spielraum, como jogo de sentidos, mantém então, internamente, uma liberdade que não se manifesta como ausência de regras, mas como liberdade para inventar sentidos no ato mesmo do jogo e é nele, na forma do jogo, ou seja, jogando, que o jogo se estabelece no acontecer de sua própria constituição. E é enquanto tal que as regras se tornam mutáveis e flexíveis, já que se exercem como jogo - o que une, numa mesma concepção, a regra ao próprio jogo (e não mais como regras do jogo, mas regra sendo jogo, formando o jogo). É como se o jogo não tivesse algo prévio a ele e estabelecesse no próprio jogar suas condições, de forma que só quem está no jogo compreende as suas regras. Eis a fórmula da seleção do nós: trata-se de um estar no jogo e, nele, suportar (não mais como um entender externo, mas como um jogar) as jogadas que formam o jogo. A regra está subsumida no próprio jogo que envolve o nós como seu personagem. Nele anula-se o sujeito que vê o jogo pela regra externa da moral e eleva-se um nós como possibilidade de incompreensão descentralizada de quem está dentro do jogo e nele se efetiva. Não há, então, um sujeito que coordena o jogo, mas um personagem que se faz no próprio jogo, ele mesmo aquilo que se efetiva no jogado e no joga- 
dor. O nós é uma manifestação do jogar, como um epifenômeno do jogo. Aí, a linguagem já não exerce mais o seu papel de nominar ou definir regras, mas ocorre pela vida do inaudito ou do incompreendido. Contudo, no jogo ao qual o nós se submete, a linguagem vivifica o que é vivido como jogo e se abre para a plenitude de sentido que não cabe na palavra. O que não se compreende é o que permanece intocável e que é um impulso originário daqueles que estão no jogo, que é, nesse sentido, atividade pré-reflexiva. O que Nietzsche explicita, pela vida do nós, portanto, é o ambiente de factibilidade de relações que não ocorrem mais pela via de um sujeito pensante que emite regras sobre a vida (ou para a vida). Trata-se agora de recorrer, hermeneuticamente, ao não dito que permanece. Não há jogo para quem permanece fora dele. Só há jogo para quem aceita o risco da incompreensibilidade e, no que não pode ser dito pela força da vivência, vivencia o risco como potencialidade. Aí a amizade vira o jogo das possibilidades e das aberturas de um exercício que não tem outro fim fora de si mesmo.

\section{CONSIDERAÇÕES FINAIS}

A amizade que se expressa pela via da incompreensão instala-se no campo de uma nova visão de virtude, não mais aquela marcada pelo desenvolvimento e melhoramento do humano, mas do reconhecimento de sua situação de transitoriedade e da riqueza maior das vivências que permanecem no campo do que é obscuro. No âmbito da amizade, o que se efetiva não são padrões de dever ou obediências, mas aberturas para além, para fora, a partir do reconhecimento do que é mais profundo como mais íntimo. Essa nova relação não passa mais pela necessidade de compreensão, já 
que implica justamente a incompreensibilidade e a força necessária para vivenciar aquilo que não pode ser comunicado e que só os espíritos mais livres poderão suportar - e quererão suportar. A virtude da amizade, agora, conduz àquilo que Nietzsche chama de moral do futuro: uma moral na qual o próprio indivíduo se faz legislador, rei de si mesmo, soberano e livre o suficiente para estabelecer regras para si mesmo sem que necessite comunicá-las à exaustão, sob o seu efetivo enfraquecimento de sentido.

Obviamente o resultado desse projeto, em termos práticos, não tem em vista a sua exequibilidade, mas os desafios que ele evoca no que tange à reavaliação e recusa dos conceitos metafísicos sobre os quais as relações humanas em geral estão pautadas, o que lhes fornece um reiterado tom decadente. Não à toa, a amizade serve de antídoto contra a pobreza das relações sociais marcadas pelo gregarismo, porque pautada sobre os enganos do pretenso eu e do outro. Como prega Zaratustra (ZA, II, Dos compassivos), é preciso eliminar os mendigos, ou seja, eliminar os sofredores que demandam caridade e ajuda em sua pobreza. É preciso eliminar a pobreza nas relações e deixar a alegria e a abundância da amizade (que é uma Mitfreunde - alegria partilhada) fecundar as relações.

Malgrado a amizade continue, nesses termos, uma relação impossível, é nela que fundamos a possibilidade de relações mais livres e saudáveis, menos dependentes, condicionadas ou submissas. A amizade é a abertura ao possível pela transgressão do que é através da experimentação do que pode se tornar. No Spielraum da amizade, o humano cresce e se doa aos pares como abundância de poder e é só desse reconhecimento que sentimentos como compaixão, simpatia, comiseração, clemência ou bondade. 
Abstract: This article intended to show the importance of friendship in the context of reflection on the incomprehensibility of living wealth experienced as more intimate experience and how Nietzsche comes, with the relationship amicable, to formulating of a new dawn of thought, now situated in the field of experience which escapes of systems responsiveness. In this scenario, friendship appears as a ring for misunderstandings because it fosters the possibility of a relationship translated by the plural pronoun us - a sign of relationship that is effective as fearlessness, freedom and assert themselves, with a view to constant self-overcoming.

Keywords: friendship; incomprehensibility; self-overcoming.

\section{REFERÊNCIAS}

BABICH, B. Nietzsche's imperative as a friend's encomium: on becoming the one you are, ethics, and blessing. In: Nietzsche-Studien 32, p. 29-58, 2003.

NIETZSCHE, Friedrich. Além do Bem e do Mal. Prelúdio a uma Filosofia do Futuro. Trad. de Paulo César de Souza. 2. ed. São Paulo: Cia. das Letras, 2002.

- Aurora. Reflexões sobre os preconceitos morais. Trad. de Paulo César de Souza. São Paulo: Cia. das Letras, 2004.

. A Gaia Ciência. Trad. de Paulo César de Souza. São Paulo: Cia. das Letras, 2002.

. Ecce Homo. Como alguém se torna o que é. Trad., notas e posfácio de Paulo César de Souza. 2. ed., 3ª reimpr. São Paulo: Companhia das Letras, 1995.

- Genealogia da Moral. Uma polêmica. Trad. de Paulo César de Souza. São Paulo: Cia. das Letras, 2002.

. Humano, Demasiado Humano I. Um livro para espíritos livres. Trad. de Paulo César de Souza. São Paulo: 
Cia. das Letras, 2000.

. Sämtliche Werke: Kritische Studienausgabe in 15 Bänden. (KSA) Hrsg. Giorgio Colli und Mazzino Montinari. Berlin/New York: DTV \& Walter de Gruyter, 1980.

OLIVEIRA, Jelson. A solidão como virtude moral em Nietzsche. Curitiba: Champagnat, 2010.

- Para uma ética da amizade em Friedrich Nietzsche. Rio de Janeiro: 7Letras, 2011.

PONTON, Olivier. Mitfreude: o projeto nietzscheano de uma "ética da amizade" em Humano, demasiado humano. Revista Estudos Nietzsche, Curitiba, n. 1, v. 1, 2010. Disponível

http://www2.pucpr.br/reol/index.php/ESTUDOSNIETZSC HE?dd1 =4335\&dd99=view. Acesso em: 18 mai. 2011.

SMALL, Robin. Nietzsche and Rée. A star friendship. Oxford; New York: Clarendon Press; Oxford University Press: 2009.

VISENTEINER, Jorge Luis. Experimento e vivência: a dimensão da vida como pathos. 2009. 337 f. Tese (Doutorado em Filosofia) - Universidade Estadual de Campinas, Campinas, 2009. 